Michał Kurzej

Instytut Historii Sztuki

Uniwersytet Jagielloński

http://dx.doi.org/10.18778/2084-851X.05.11

\title{
Ołtarz jako okno i lustro w konceptach ks. prof. Sebastiana Piskorskiego
}

$\mathrm{P}$

orównanie ołtarza zarazem do okna i lustra zostało zaproponowane w opisie nastawy kościoła rzymskiego S. Andrea al Quirinale. Jej zwieńczenie, ukazujące chwałę świętego, otwiera się na boską rzeczywistość, a pole odzwierciedla naśladowanie ofiary Chrystusa przez apostoła ${ }^{1}$. Jak zauważył Jacek Kowalski, skojarzenie ołtarza $\mathrm{z}$ lustrem ma interesujący precedens $\mathrm{w}$ polskim dziele literackim. Jest nim anonimowy poemat o oblężeniu Jasnej Góry, którego fragment opisuje wizję niebiańskiej świątyni, czyli kościół wysoki ani dościgniony / Okiem ni żadna ręka urobiony, którego ołtarz jest zwierciadłem, ukazującym sprawy Boskie ${ }^{2}$.

Podwójna metafora ołtarza jako okna i lustra pasuje szczególnie dobrze do szeregu nastaw zaplanowanych przez ks. prof. Sebastiana Piskorskiego. Oprócz tradycyjnej i zupełnie powszechnej funkcji oprawy przedstawienia osoby bądź sceny ukazującej nadprzyrodzoną rzeczywistość - działają również jak zwierciadło. W określonych momentach przyjmują światło słoneczne, które wywołuje w nastawie krótkotrwały efekt luministyczny, otwierając przed widzem nową warstwę znaczeniową. Piskorski, profesor prawa Uniwersytetu Jagiellońskiego a także popularny poeta i kaznodzieja, stał się centralną postacią życia artystycznego, uczestnicząc jako konceptor i prowizor w powstawaniu najciekawszych kompleksowych dzieł 
sztuki sakralnej ${ }^{3}$. Nastawy ołtarzowe odgrywają w nich szczególną rolę semantyczną, będąc kluczem do odczytania programu ikonograficznego. Ich treści są też integralnie związane z formą, która - jak zauważyła Zofia Maślińska-Nowakowa - bez znajomości przedstawionego sensu nie może być właściwie oceniona ${ }^{4}$.

Działalność prowizorów była już w polskiej literaturze omawiana przez Tadeusza Mańkowskiego ${ }^{5}$, Zbigniewa Banię i Tomasza Kunkla. Przeważnie byli oni związani z dworami prowadzącymi stałą działalność inwestycyjnąa lub nadzorowali przedsięwzięcia budowlane z ramienia instytucji, pełniąc funkcję „inwestora zastępczego" ". W obu przypadkach przejmowali od fundatora bardzo szerokie kompetencje, nadzorując przedsięwzięcie od strony finansowej i artystycznej oraz podejmując decyzje o zatrudnieniu poszczególnych wykonawców.

Zdecydowanie mniej wiadomo o twórczości konceptorów, której charakter trzeba rekonstruować z rozproszonych w literaturze wzmianek. Wskazują one, że wzrost wymagań w stosunku do treści złożonych dzieł sztuki, jeszcze w XVI wieku, doprowadził do specjalizacji i profesjonalizacji układających je osób. Podejmowali się tego tylko najambitniejsi i najlepiej wykształceni artyści, a znacznie częściej pisarze i uczeni, na co wskazują przykłady znane ze sztuki włoskiej. W takim charakterze działał Fulvio Orsini, bibliotekarz, antykwariusz i numizmatyk, któremu proponowano objęcie katedry na uniwersytecie krakowskim lub wileńskim. Pracując dla kardynałów Farnesich, kolejno Ranuccia, Alessandra i Odoarda, układał on programy malowideł, m.in. dla wnętrz rezydencji w Capraroli'. Na początku następnego stulecia działał Giovanni Battista Agucchi, arystotelik, krytyk literacki i teoretyk sztuki, którego poglądy przyczyniły się do powrotu mody na formy klasyczne. Agucchi uważał, że mecenas musi być prowadzony przez wyspecjalizowanego znawcę sztuki. Prawdopodobnie pełnił taką właśnie rolę na dworze Farnesich, a według niektórych badawczy był twórcą programu ikonograficznego galerii w ich rzymskim pałacu ${ }^{10}$. W siedemnastowiecznej Italii z pomocy konceptorów korzystano przy planowaniu najwybitniejszych dekoracji malarskich. Program fresku, którym Pietro da Cortona ozdobił w latach 1632-1639 główną salę rzymskiego Palazzo

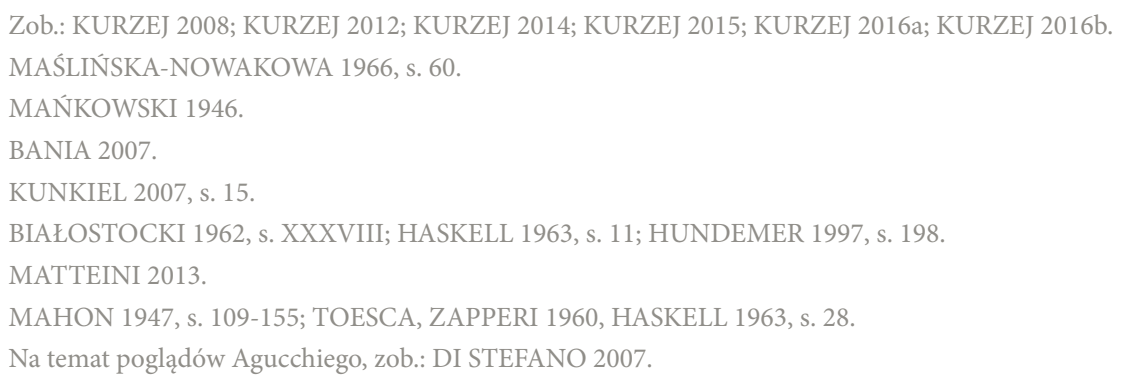


Barberini, ułożył Francesco Bracciolini, ulubiony poeta Urbana VIII, znany jako autor mało wyrafinowanych poematów panegirycznych. Przy planowaniu dekoracji sklepienia kościoła Il Gesù współpracowali Bernini, Baciccia i generał zakonu jezuitów Giovanni Paolo Oliva, który przypuszczalnie pełnił rolę konceptora ${ }^{11}$. Program malowideł w turyńskim Palazzo Carignano, wykonanych w latach 1699-1703 przez Stefana Marię Legnaniego, napisał Ercole Agostino Berò, dworzanin związany z kręgami uniwersyteckimi Bolonii ${ }^{12}$.

Pierwszym dziełem Piskorskiego jest założenie pielgrzymkowe w Grodzisku koło Skały, zrealizowane w latach 1677-1691. Upamiętnia ono bł. Salomeę, pierwszą polską klaryskę, która według tradycji mieszkała tam, a potem zmarła 17 listopada $1268 \mathrm{roku}^{13}$. Na świt w tym dniu zorientowana była wcześniejsza grodziska kaplica, zbudowana za rządów ksieni Eufrozyny Stanisławskiej około roku 1640. Piskorski

Grodzisko, Kościół Wniebowzięcia NMP, ottarz gł., fot. Michał Kurzej, 2013
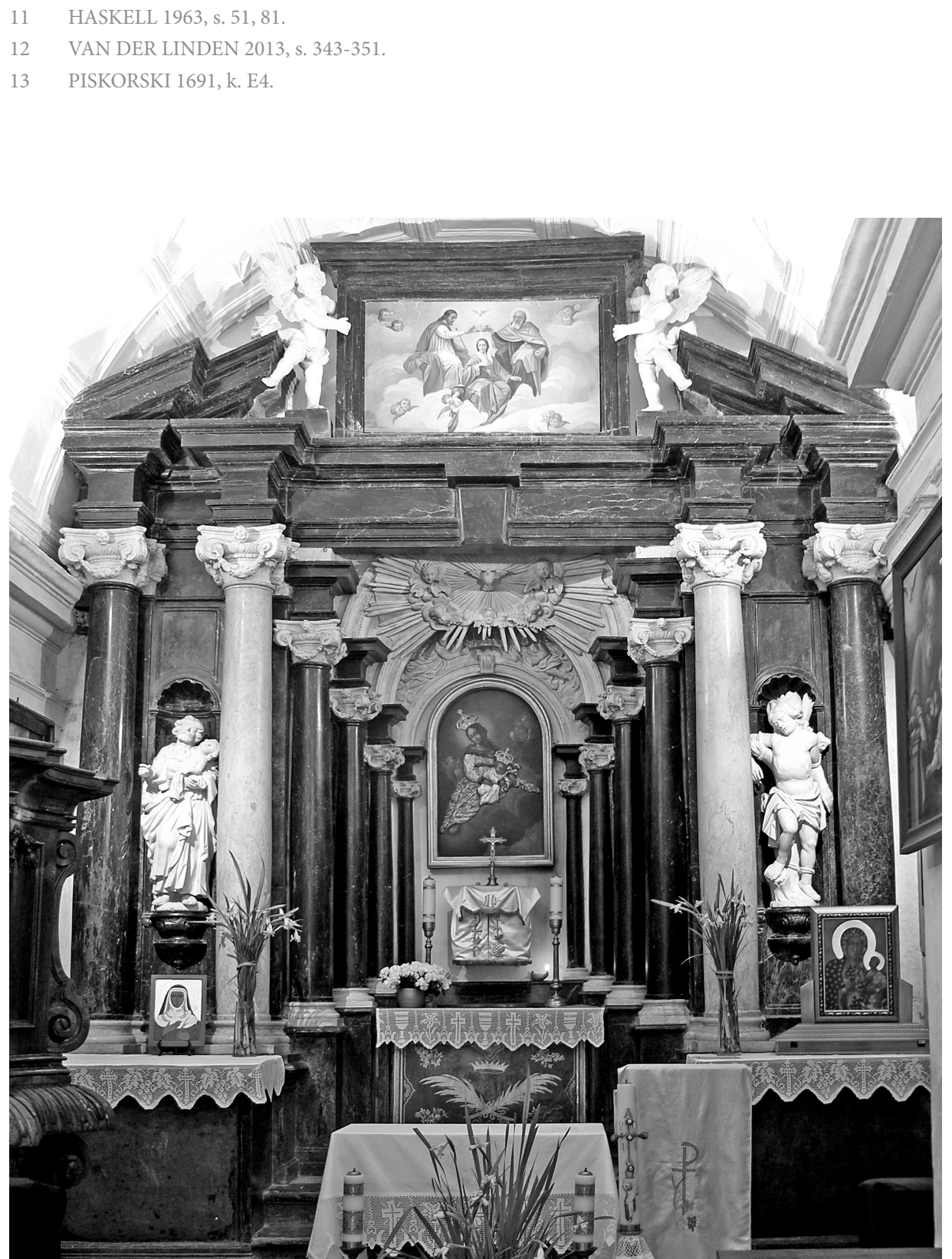


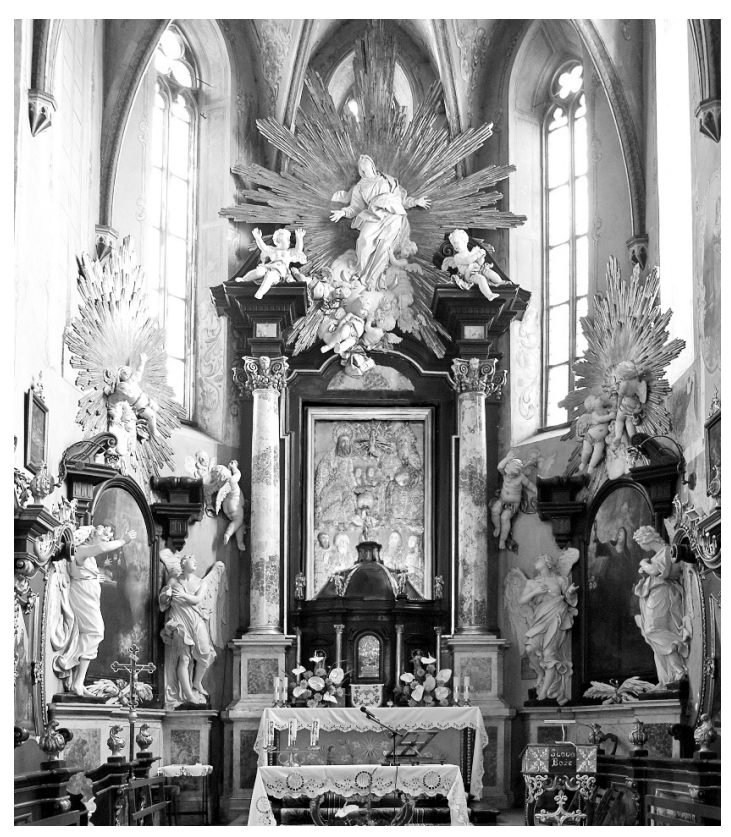

Stary Sącz,

Kościół Klarysek, ołtarz gł., fot. Michat Kurzej, 2014

przekształcił ją w kościół, zmieniając orientację w ten sposób, że tego dnia pierwsze promienie słońca mogły padać na ołtarz, ukierunkowane przez wejście oraz parę drzwi, stojącego naprzeciw, domu kapelana. Z powodu jego późniejszych przeróbek efekt ten nie jest obecnie widoczny. Można jednak przypuszczać, że współgrał z perspektywiczną architekturą ołtarza i pozwalał podkreślić jego warstwę znaczeniową, której najważniejszym elementem był obraz bł. Salomei w polu środkowym, zasuwany wizerunkiem Wniebowzięcia NMP ${ }^{14}$. Niezwykłość ołtarza w Grodzisku polega również na zastosowaniu trzech mens do odprawiania Mszy Świętej dobrze zgodny $\mathrm{ch}^{15}$, których zwielokrotnienie wpisywało się w złożoną trynitarną symbolikę wnętrza. Później, najprawdopodobniej również z inicjatywy Piskorskiego, triadę ołtarzy wprowadzono też w kościele klarysek w Starym Sączu, tam jednak, odwrotnie niż w Grodzisku, zastosowano trzy nastawy a jedną mensę ${ }^{16}$.

Okazję do wykorzystania znacznie wspanialszych rozwiązań artystycznych Piskorski dostał wkrótce po ukończeniu prac w Grodzisku. Wtedy to, w roku 1692, uniwersytet powierzył mu kierowanie pracami przy budowie nowej kolegiaty pw. św. Anny ${ }^{17}$. Można przypuszczać, że jeszcze przed przystąpieniem do nich wziął on udział w dyskusji nad usytuowaniem i projektem kościoła, aby w ten sposób 
wpłynąć na rozmieszczenie jego głównych nastaw. Tylko dzięki ich konkretnemu usytuowaniu można było wykorzystać światło słoneczne do ołtarzy w prezbiterium i obu ramionach transeptu z momentami roku słonecznego. W ten sposób włączono te momenty do najważniejszych wątków programu treściowego budowli ${ }^{18}$. Jej szczególnie ważnym elementem jest ołtarz z relikwiami patrona uniwersytetu, św. Jana Kantego, który dawniej uważano za zmodyfikowane powtórzenie berninowskiego baldachimu nad grobem św. Piotra. Ryszard Mączyński określił je jako cyborium bezbaldachimowe, uznając że baldachim jako ekwiwalent nieba okazał się zbędny,

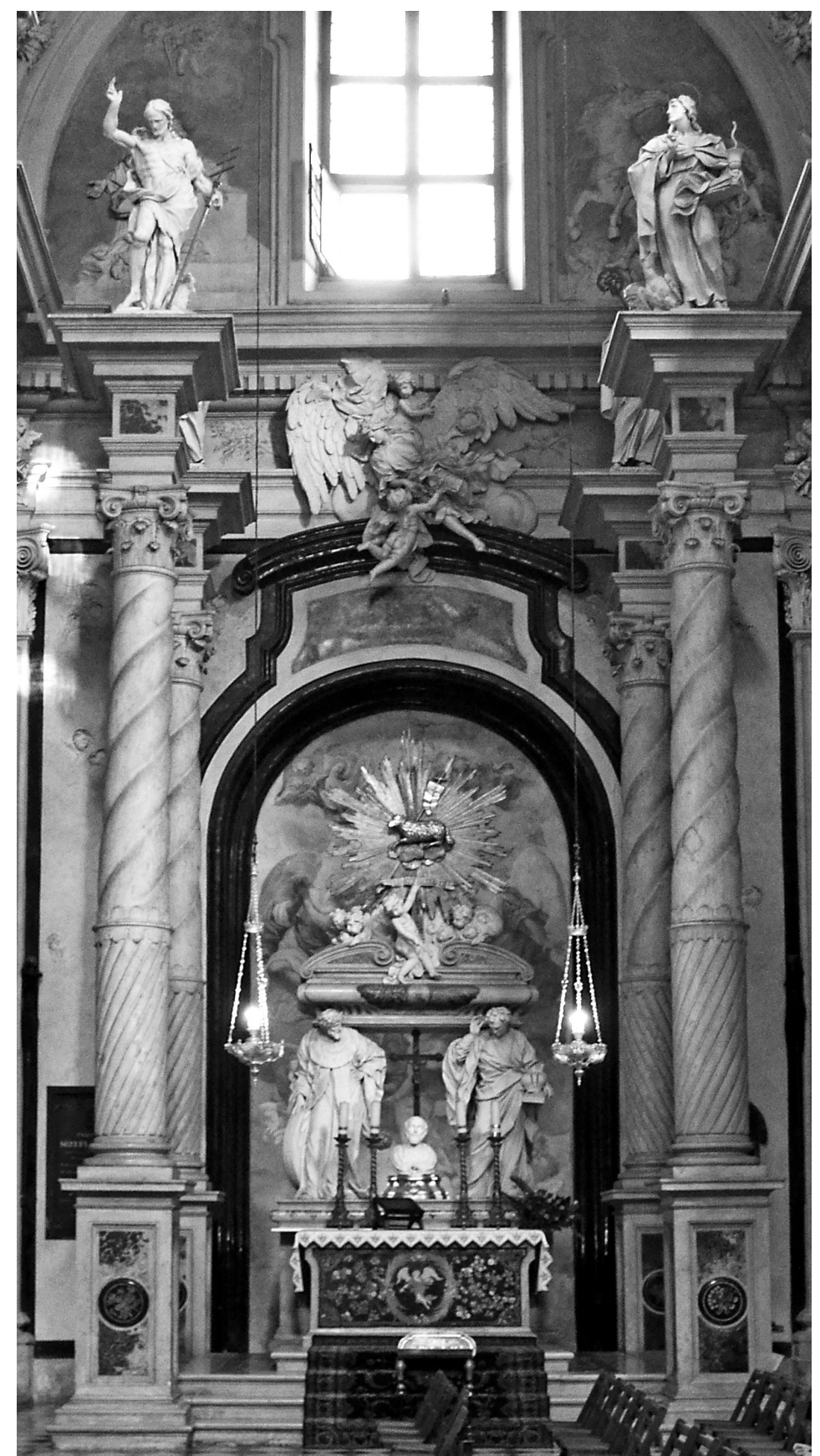


gdyż granicę tej sfery wyznaczały figury czterech powszechnie czczonych świętych

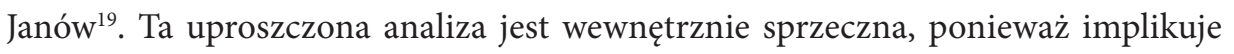
zbędność baldachimu w dziele Berniniego, gdzie granicę strefy niebiańskiej wyznaczają figury czterech aniołów. Ponadto odwraca uwagę od właściwego pierwowzoru, którym nie jest zrealizowane dzieło Berniniego, ale jeden z jego wstępnych projektów watykańskiego ołtarza tronu św. Piotra ${ }^{20}$ i uniemożliwia to odczytanie treści mauzoleum.

Kluczem do ich zrozumienia jest kult krakowskiego profesora, który promowano podaniem o otrzymaniu przez niego nadprzyrodzonego oświecenia, pochodzącego od samego Chrystusa. Na mauzoleum zostało ono zobrazowane przez figurę Baranka oraz putto z podpisem Et lucerna eius est, wskazujące na nią i na relikwie świętego, niesione przez personifikacje czterech wydziałów. Otaczające grób kolumny nie są zaś nawiązaniem do kręconych podpór baldachimu nad grobem apostoła, ale do ich pierwowzorów z białego kamienia, które według tradycji pochodzą ze świątyni Salomona. Ustawiono na nich figury świętych imienników profesora, którzy jak on byli wybitnymi kaznodziejami i teologami. Jeden z nich, Jan Chrzciciel, wskazuje na wizerunek Baranka, który jest zarazem jego atrybutem ${ }^{21}$, przypominając, że Kanty nosił imię na jego cześć i urodził się w jego święto, przypadające w przesilenie letnie. Popołudniami około tej daty promienie słońca, padające z przeciwległego okna transeptu, oświetlają tę kompozycję, podkreślając jej sens i wskazując, że Opatrzność przeznaczyła Kantego do świętości już samym momentem urodzenia. Światło odbija się od srebrzonej figury Baranka i otaczającej ją złoconej glorii jak od lustra, padając wtedy na wiernych, klęczących przed ołtarzem, co można interpretować jako przekazywanie im oświecenia dostępnego świętemu. W XVII wieku za namacalne świadectwo tej iluminacji uchodziły zachowane w bibliotece uniwersyteckiej rękopisy, które błędnie wiązano z Janem, mimo że w Krakowie nie potrafiono ich przeczytać22.

Efekty polegające na odbijaniu naturalnego światła słonecznego zaplanowano też na pozostałych dwóch z trzech najważniejszych ołtarzy kolegiaty. Wizerunek umieszczony pod oknem oświetlającym grób Kantego przypomina o jego pasyjnej pobożności. W jego polu umieszczono olbrzymi relief przedstawiający triumf unoszonego przez anioły krzyża, adorowanego przez św. Jana Ewangelistę i Matkę Boską, podtrzymującą martwe ciało Chrystusa. Promienie słońca padają na ten

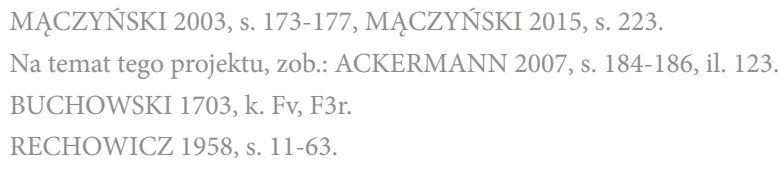




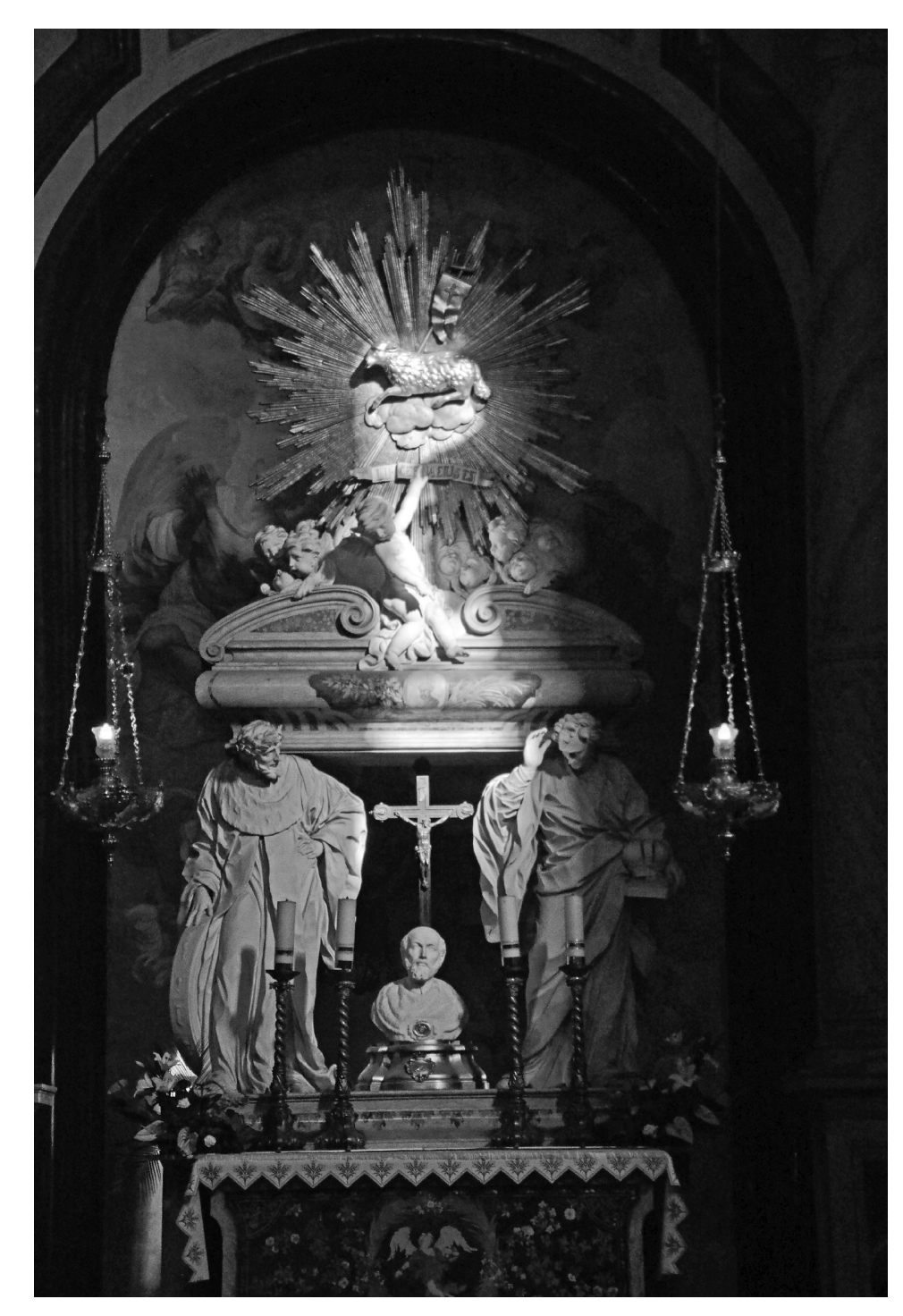

w przesilenie letnie, fot. Michał Kurzej, 2015

element kompozycji rankiem w dniach około równonocy, przypominając o dacie śmierci Jezusa, określanej tradycyjnie - tak samo jak poczęcie - na 25 III. Z kolei obraz w ołtarzu głównym oświetlony jest bezpośrednio na przełomie grudnia i stycznia, kiedy snop światła padający przez okno w fasadzie, tworzy wieczorami naturalną aureolę nad głowami ukazanych postaci. Najważniejszą z nich jest Dzieciątko Jezus, którego narodzenie kojarzono powszechnie z przesileniem zimowym, a wigilia tego święta jest także rocznicą śmierci Kantego. Ołtarz łączy więc symbolikę chrystologiczną i uniwersytecką. Z tą ostatnią wiąże się już sama postać patronki kościoła, która miała przekazać Marii odnoszące się do niej proroctwa, co stało się 


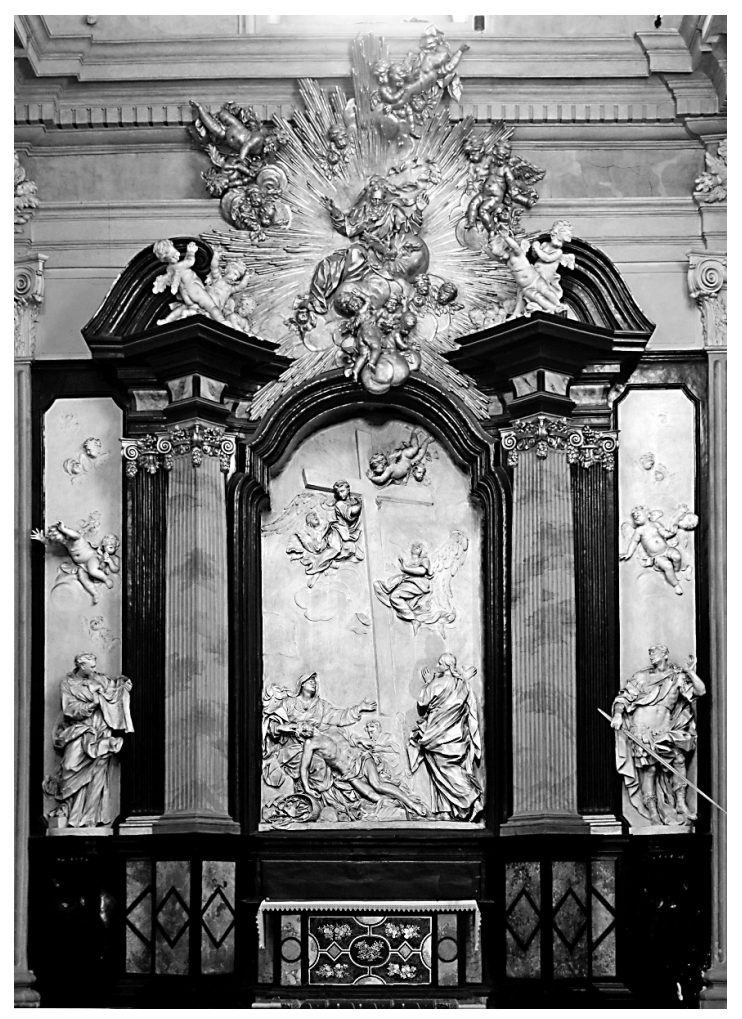

pretekstem do zaprezentowania jej jako patronki nauczycieli teologii ${ }^{23}$. Do przekazywania prawdy o pochodzeniu Chrystusa odnosi się też trzymana przez anioły karta z retorycznym pytaniem Generationem eius quis enarrabit? Odpowiedzią jest, stanowiąca zwieńczenie ołtarza, gloria z księgą, w której wypisano pierwsze słowa Ewangelii wg św. Mateusza, a jej kolejne wersy rozmieszczono na fryzie łączącym prezbiterium, transept i nawę kościoła. Jest to kolejna aluzja do rzekomej pracy teologicznej Kantego, będącej komentarzem tego właśnie tekstu.

W starszych badaniach nad dziełami sztuki nowożytnej praktyczne wykorzystanie naturalnego światła postrzegano przeważnie, w oderwaniu od jego symboliki, jako środek wyrazu artystycznego, analizowany zazwyczaj w kontekście inspiracji twórczością kręgu Berniniego. Dotyczyło to też inwencji Piskorskiego, w którego działalności dostrzegano wyraz fascynacji sztuką wielkiego artysty rzymskiego $^{24}$. Berninowskie camere di luce pozwalały na wprowadzenie do kompozycji światła, ukrytego padającego niebezpośrednio, a więc też w znacznym stopniu niezależnie od pory dnia i roku. Natomiast najbardziej spektakularne efekty świetlne 


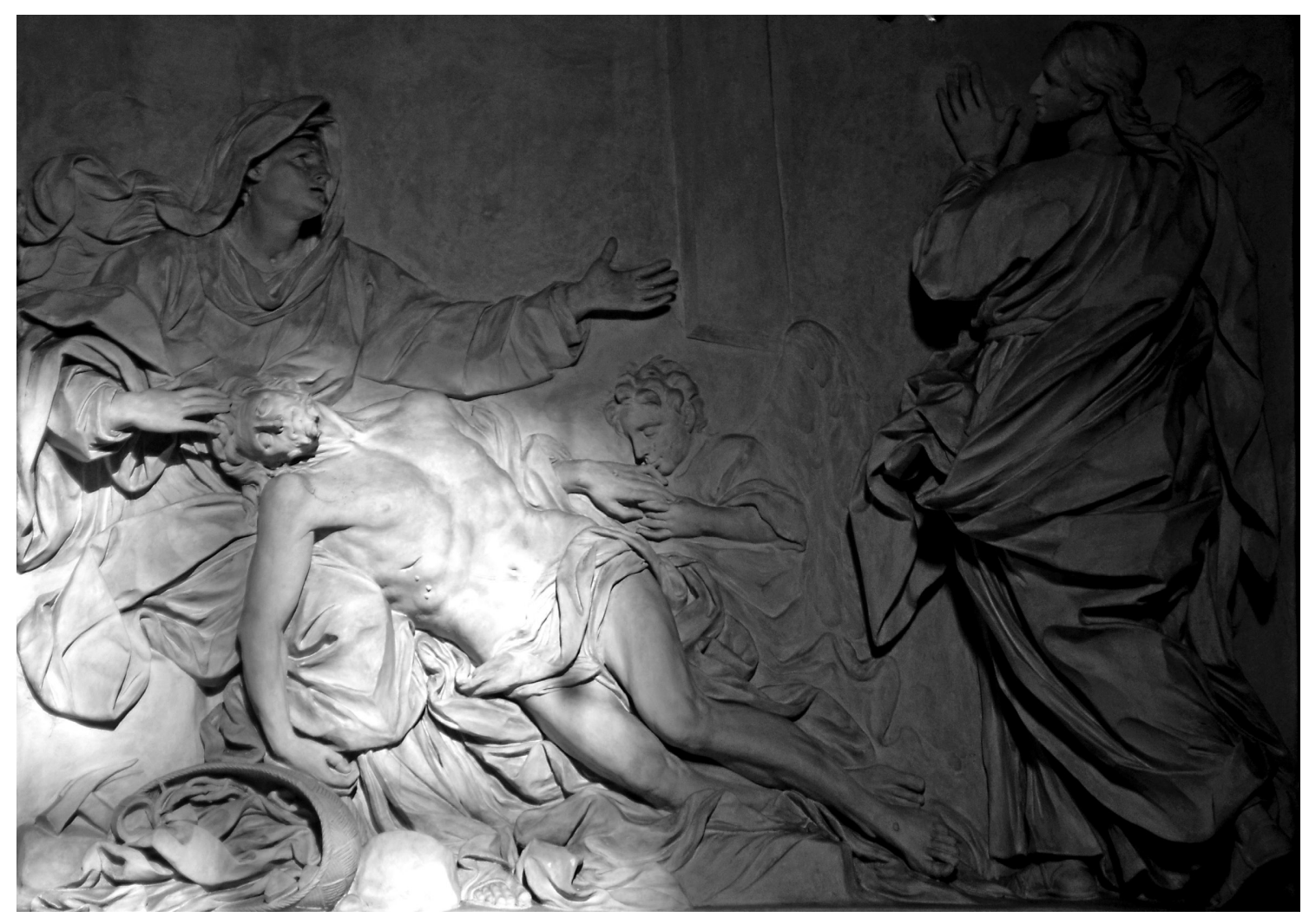

Kraków, kościół św. Anny, oświetlenie reliefu w ottarzu św. Krzyża w równonoc, fot. Michat Kurzej, 2016

Kraków, kościół św. Anny, oświetlenie obrazu w ołtarzu gł. między świętami Bożego Narodzenia a Trzech Króli, fot. Michał Kurzej, 2014

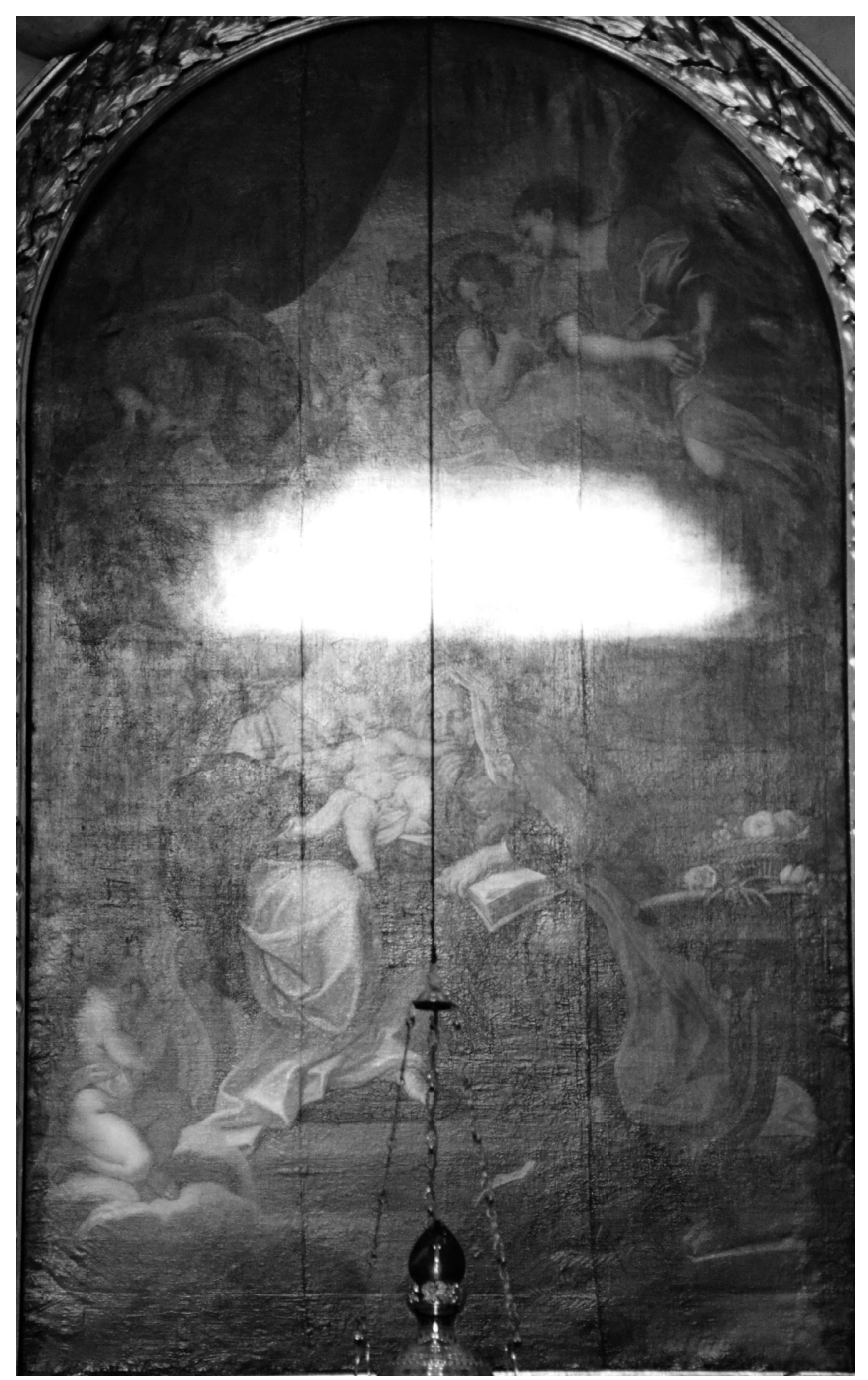


Piskorskiego wykorzystują wąskie strumienie światła, padające na wprost i jak punktowy reflektor wydobywające konkretny element wnętrza przez krótki moment, możliwy do zaobserwowania w kilka do kilkunastu dni roku. Mechanizm ich działania jest więc zupełnie inny, a to oczywiście wiąże się nie tylko z innym znaczeniem symbolicznym, ale też z odmiennym charakterem przekazu, skierowanego do innej - z konieczności o wiele węższej - grupy odbiorców. Takie wykorzystanie światła nie ma - jak dotąd - znanych analogii w sztuce nowożytnej, przez co przypadek Piskorskiego wydaje się zupełnie wyjątkowy. Operowanie przez niego światłem, podobnie jak w dziełach rzymskich, ma wyraźny charakter teatralny. Jednak, gdy w Rzymie jest ono przede wszystkim jednym z środków wyrazu, służących wzmocnieniu dramatyzmu kompozycji, to w Krakowie odgrywa istotną, choć krótkotrwałą rolę w scenariuszu, jakim jest program treściowy wnętrza.

Podobne efekty świetlne Piskorski zaplanował też na innych elementach wnętrza kościoła, zaznaczając daty związane ze świętymi patronami Polski, a także świętami Niepokalanego Poczęcia Marii, Objawienia Pańskiego i Wszystkich Świętych. Wykorzystywał też światło do podkreślenia nadprzyrodzonego charakteru przedstawienia w polu nastawy, wprowadzając je za pomocą ukrytej studni świetlnej. Najbardziej znanym przykładem jest ołtarz kaplicy Matki Boskiej, w którym iluminacja figury Niepokalanie Poczętej Marii, działająca najsilniej około południa między majem a lipcem, odrywa ją od tła, wzmagając wrażenie unoszenia w powietrzu. Szczególna oprawa tej nastawy jest ważnym elementem wątku pochodzenia Chrystusa, zaznaczonego w ołtarzu głównym. Kompozycyjnie i ideową należą do niej posągi Anny i Joachima, które wraz z figurą w ołtarzu tworzą grupę przypominającą typ ikonograficzny Arboris Virginis ${ }^{25}$. Patronka kościoła wskazuje gestem na ołtarz kaplicy, a w dłoni trzyma różę, będącą jednym z symboli jej córki. Związek matki z córką podkreśla naturalne światło, padające na figurę z okna fasady popołudniami w święto Narodzenia Marii, przypadające ósmego września. Uzupełnieniem tej kompozycji było antependium in cujus medio Imago Magnae Dei Matris, adinstar speculi elucet ${ }^{26}$, czyli zapewne owalne lustro ${ }^{27}$, na którym narysowano (lub może wygrawerowano) wizerunek Matki Boskiej. Prawdopodobnie był on półprzeźroczysty. Mógł więc odbijać środkowe pole umieszczonego naprzeciwko antependium

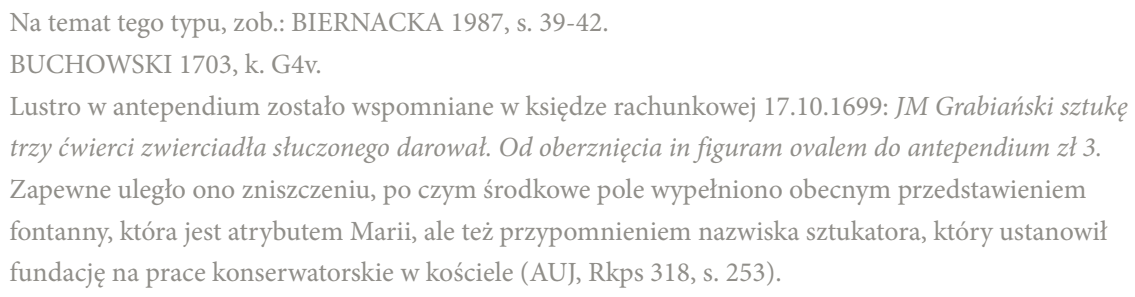


Kraków, kościół św. Anny, ołtarz Wniebowzięcia NMP,

fot. Michał Kurzej, 2015

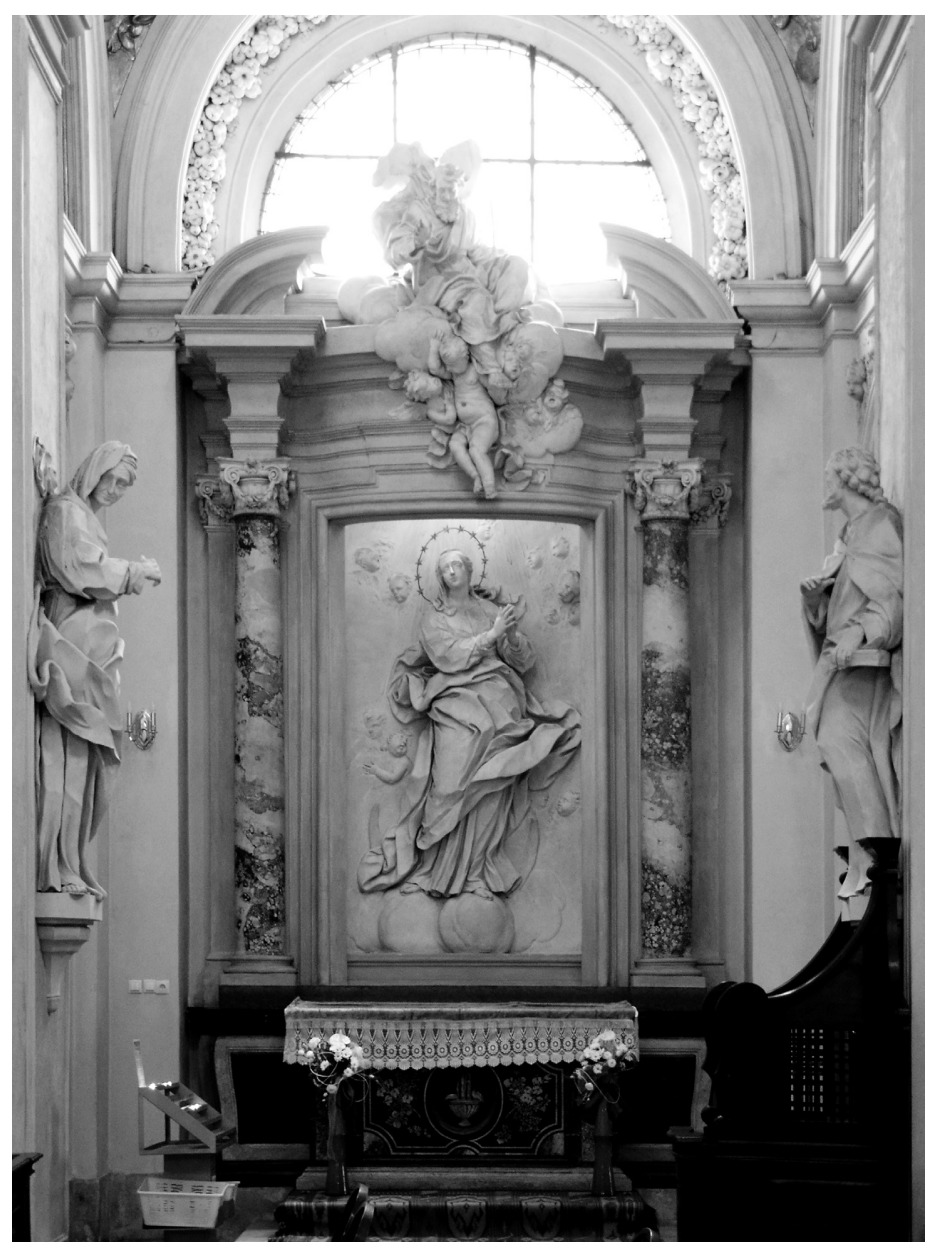

kaplicy św. Katarzyny, na którym ukazano Dzieciątko Jezus. W nawiązaniu do litanii loretańskiej, koncept ten ukazywał więc Marię jako Zwierciadło Sprawiedliwości Bożej, a może również (w zależności od kąta patrzenia) pozwalał dostrzec nowo narodzonego Chrystusa jako kolejny element genealogicznej kompozycji kaplicy, obejmującej Jego Matkę i jej rodziców.

Podobny efekt mogła dawać studnia świetlna w ołtarzu bł. Salomei, urządzonym przy południowej ścianie krakowskiego kościoła klarysek, który pierwotnie mieścił stiukową figurę księżnej ${ }^{28}$. Zakładając, iż ta rzeźba, podobnie jak inne elementy wystroju kościoła $\mathrm{z}$ tego materiału, była dziełem Baltazara Fontany, można 
przypuszczać, że jej forma nawiązywała do sztuki rzymskiej kręgu Berniniego. Podobnie zresztą jak kamienna figura błogosławionej w Grodzisku, ukazując ją unoszoną na obłoku i spoglądającą ku górze, w kierunku źródła światła. Niewykluczone, że właśnie figura w ołtarzu kościoła św. Andrzeja była wzorem, który Piskorski polecił skopiować w kamieniu i ustawić w bocznej nastawie kościółka w Grodzisku²9.

Istotnym nośnikiem treści mogły być nie tylko przedstawienia w polach ołtarzy, ale też sama ich architektura. Oprócz wspomnianych kręconych kolumn mauzoleum św. Jana, charakterystycznym przykładem jest ołtarz św. Katarzyny w kościele św. Anny. W jego polu ukazano wizję świętej, której ukazuje się Dzieciątko Jezus wyobrażone w glorii zwieńczenia. Nadprzyrodzony charakter tego zdarzenia, polegający na przenikaniu się rzeczywistości ziemskiej i niebiańskiej, współgra z formą nastawy. W dolnej części jest ona klasyczną edikulą, a w górze nabiera charakteru swobodnej kompozycji rzeźbiarskiej, odrealnionej przez wykorzystanie padającego z góry światła. Jej kolumny, niknące u góry w stiukowych obłokach, można interpretować jako wspomniany w Starym Testamencie columnam nubis - słup obłoku, w którym Bóg objawia się Żydom na pustyni (Księga Wyjścia 13, 21-22) i który jest podstawą Jego tronu (Księga Koheleta 24, 7) ${ }^{30}$.

W porównaniu z konceptami rzeźbiarskich ołtarzy kościoła św. Anny cztery nastawy $\mathrm{z}$ obrazami mogą wydawać się konwencjonalne. Zasługują jednak na uwagę, jako modelowe przykłady ołtarza o charakterze okna, otwierającego się do nadprzyrodzonej rzeczywistości. Aspekt ten podkreślają postaci aniołów, które wskazują bądź podtrzymują płótna, a także uczestniczą w namalowanych scenach. Mimo podobnej konwencji uwagę zwraca formalne zróżnicowanie obrazów, które Piskorski osiągnął starannie dobierając ich autorów. Silnie idealizowane przedstawienia śś. Józefa i Piotra o żywej, bogatej kolorystyce wykonał bolończyk Innocenty Monti $^{31}$. Stonowany i dramatyczny Chrzest Chrystusa przedstawił osiadły w Nysie Szwed Karol Dankwart ${ }^{32}$, zaś monumentalne ciało św. Sebastiana namalował Paolo Pagani, będący jednym z najlepszych ówczesnych specjalistów od aktu. Tym ostatnim dziełem, znacznie przewyższającym pozostałe zarówno wartością, jak i klasą artystyczną ${ }^{33}$, Piskorski wyróżnił kaplicę swojego patrona, którą najpierw urządził własnym kosztem, aby zachęcić innych ofiarodawców ${ }^{34}$.

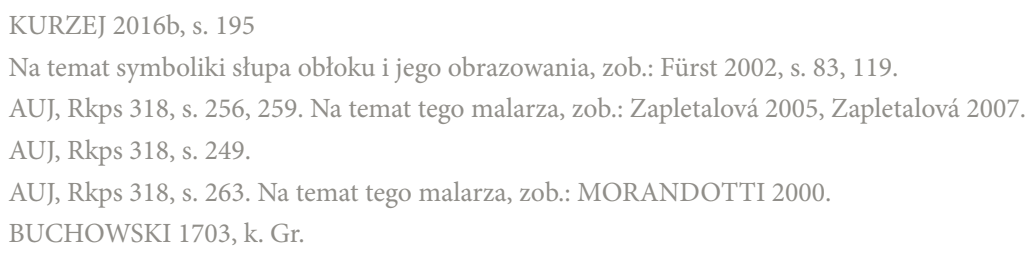


Jedynym krakowskim dziełem, które warto zestawić z powstałymi przy udziale Piskorskiego, jest nowa aranżacja dominikańskiej kaplicy św. Jacka. Z dużym prawdopodobieństwem można przyjąć, że kaplicę przekształcono za przeoratu Kazimierza Napolskiego (1694-1703), który trwał przez cały udokumentowany okres krakowskiej działalności Fontany. Zapisał się on w zakonnej pamięci m.in. ozdobieniem kościoła statuq S. Jacka nad grobem jego i promieniami około niej, co prawdopodobnie odnosi się wprost do nowej aranżacji pochówku, a przynajmniej świadczy o zainteresowaniu oprawą artystyczną tego miejsca ${ }^{35}$.

Promocja czci dla świętego założyciela była oczywiście przedmiotem szczególnych starań innych krakowskich dominikanów. Wyróżnił się na tym polu poprzednik Napolskiego, Dominik Frydrychowicz, który jednak nie długo przeorowat, dla zabaw ustawicznych $w$ pisaniu ksiag, wolał nieustanne lekcje, niżeli gospodarskie turbacje ${ }^{36}$. Jedną z ciekawszych jego prac jest obszerna apologia kultu Jacka, ilustrowana ciekawymi, choć nieporadnymi rycinami Tobiasza Steckla i poprzedzona panegirykiem Stanisława Bieżanowskiego, sławiącym go w imieniu uniwersytetu. Głosi ona chwałę świętego jako głównego patrona królestwa, eksponując związki rodu Odrowążów z innymi świętymi, królami Polski oraz świeckimi i duchownymi dostojnikami. Ten rozbudowany opis pokrewieństwa i powinowactwa miał zapewne oddziałać na adresata dedykacji, którym był wojewoda sieradzki Jan Chryzostom Odrowąż-Pieniążek ${ }^{37}$, szwagier Franciszka Szembeka, który zatrudniał Piskorskiego jako wychowawcę synów. Nie wiadomo wprawdzie czy ta publikacja okazała się skuteczną zachętą do ofiar na odnowienie miejsca spoczynku świętego krewniaka, ani tym bardziej, czy Piskorski brał w tym przedsięwzięciu jakikolwiek udział. Przynajmniej w charakterze doradczym ten udział był jednak możliwy, chociażby ze względu na zaangażowanie popieranych przez profesora artystów oraz bliskie związki uniwersytetu z zakonem ${ }^{38}$.

Najważniejszym elementem kaplicy jest nagrobek w formie tumby unoszonej przez anioły i zwieńczonej stojącą figurą świętego. Jego forma stała się przyczyną interesującej kontrowersji badawczej. Olgierd Zagórowski wnioskował o zależności krakowskiego nagrobka od znacznie późniejszego relikwiarza św. Jana Nepomucena $^{39}$, a Mariusz Karpowicz i Ryszard Mączyński uznali krakowską kompozycję

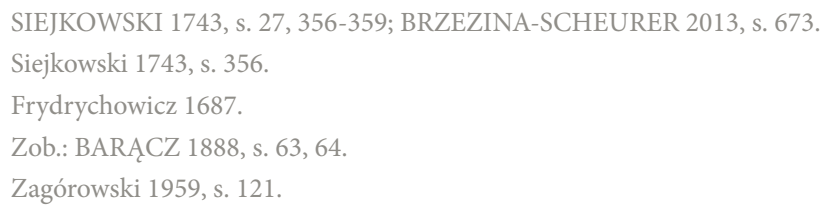




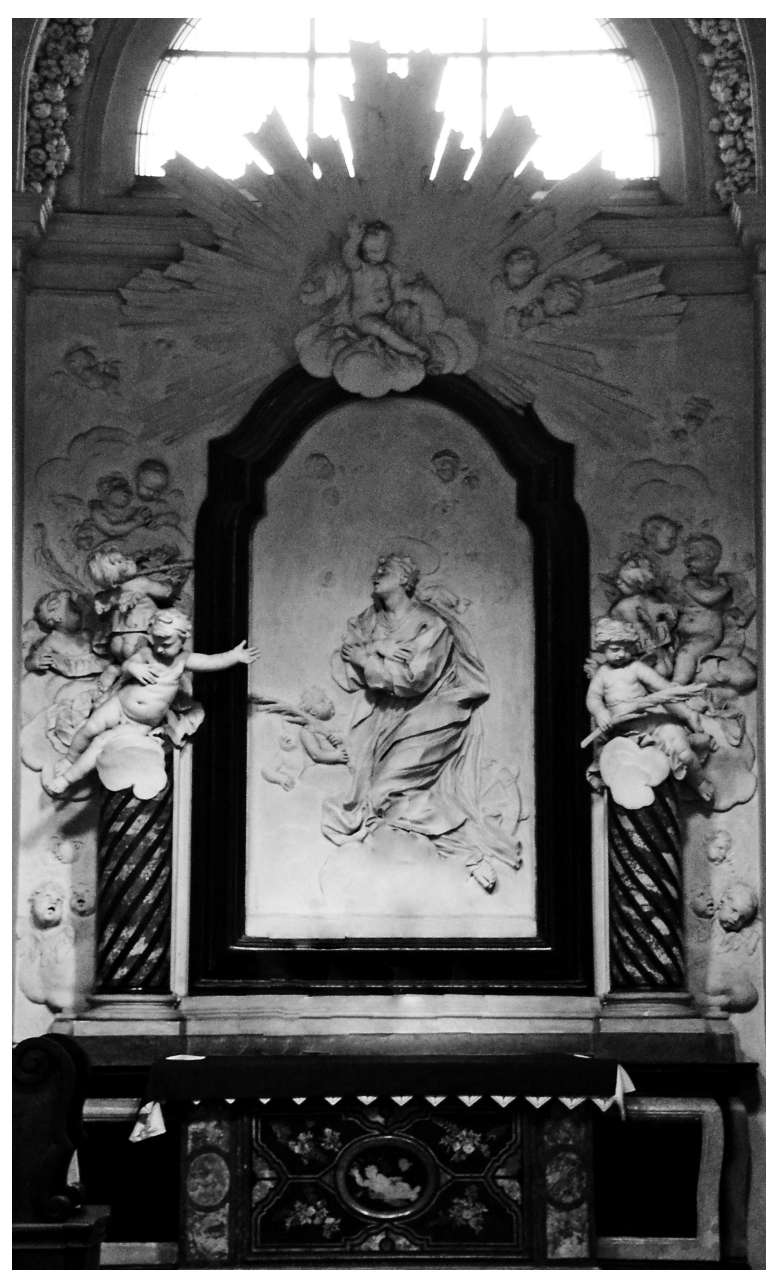

Kraków, kościół św. Anny, ołtarz św. Katarzyny, fot. Michał Kurzej, 2017

za niezwykłą w skali Europy ${ }^{40}$. Ten ostatni badacz stwierdził nawet, że relikwiarze podtrzymywane przez anioły nie występują w sztuce włoskiej ${ }^{41}$, co jest spektakularnym przykładem ignorowania dokonań pozarzymskich centrów artystycznych. Do najważniejszych z nich należy niewątpliwe Wenecja, gdzie takie dzieła zyskały szczególną popularność dzięki ołtarzom głównym wykonanym według koncepcji Baldassara Longheny w dwóch wyspiarskich katedrach. Pierwszy z nich, na Torcello, z roku 1629 zawiera relikwie św. Heliodora z Altino, drugi w San Pietro di Castello, zaczęty w roku 1649 - św. Wawrzyńca Giustignaniego. Rozwiązania te zaczęto szybko adaptować do struktur przyściennych. Przykładem tego jest ołtarz św. Maksymina w kościele San Cassiano, wykonany w roku 1639 przez Clementa

40 KARPOWICZ 1994, s. 59, 60; MĄCZYŃSKI 2003, s. 131-133.

41 MĄCZYŃSKI 2014, s. 63. 
Kraków, kościół Dominikanów, oświetlenie ołtarza św. Jacka w święto Wniebowzięcia NMP, fot. Michał Kurzej, 2016

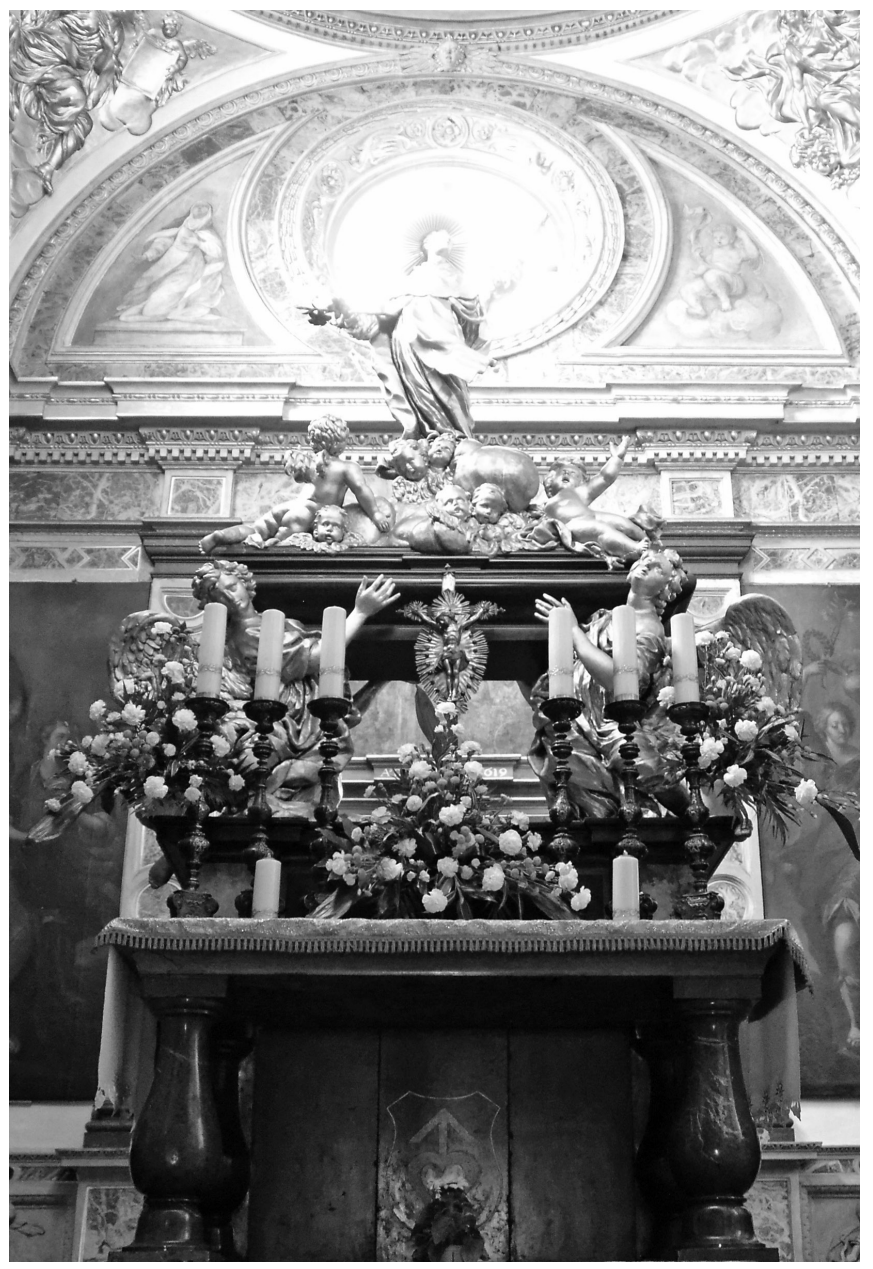

Mollego oraz relikwiarz św. Krescencjona w Santa Maria della Salute, projektu Justa Le Courta, odkuty przez Michela Fabrisa w latach pięćdziesiątych wieku XVII ${ }^{42}$. Około roku 1680 parę takich nastaw, z relikwiami śś. Niewiniątek (zwieńczony figurą płaczącej matki) i św. Juliana, wykonał Giovanni Comin, według projektu Alessandra Tremignona, do kościoła Santa Giustina w Padwie ${ }^{43}$, który był dobrze znany krakowskim akademikom. Dlatego można przypuszczać, że poza miejscową tradycją podstaw relikwiarza w kształcie figur aniołów, źródłem takiego rozwiązania były właśnie wzory włoskie.

Właściwym powodem takiej kompozycji ołtarza z relikwiami św. Jacka mogła być chęć zaaranżowania efektu świetlnego o charakterze kalendarzowym. 
Usytuowanie kaplicy na piętrze, po północnej stronie prezbiterium kościoła, przez większą część roku uniemożliwiało bezpośrednie oświetlenie jej wnętrza światłem słonecznym. Wyjątkiem są jedynie poranki dni około połowy sierpnia, kiedy to jego promienie wpadają przez okno w ścianie wschodniej, pozwalając na zaakcentowanie dat śmierci i wspomnienia świętego szczególnym oświetleniem jego mauzoleum. Padają one z tyłu na figurę świętego, widoczną na tle okna dla wiernych klęczących $\mathrm{w}$ arkadzie wejściowej ${ }^{44}$. Jak zauważyła Katarzyna Brzezina-Scheurer, efekt ten mógł być pierwotnie zmodyfikowany przez glorię promienistą ${ }^{45}$. Wobec braku informacji na temat jej kształtu i wielkości, trudno sobie jednak wyobrazić, na czym polegała ta zmiana. Można jedynie przypuszczać, że promienie, będące tłem dla figury, przede wszystkim zwiększały jej widoczność w sztucznym świetle padającym od strony wejścia ${ }^{46}$, odtwarzając częściowo jej krótkotrwałą ekspozycję słoneczną. Możliwe też, że nie były one stałym elementem nagrobka, ale zawieszano je przy nim okresowo, w związku z konkretnymi uroczystościami.

Podobieństwo tego rozwiązania do efektów stosowanych przez Piskorskiego, jak również zatrudnienie popieranych przez niego wykonawców, pozwala przypuszczać, że miał on jakiś udział w powstaniu tego dzieła. $Z$ drugiej strony nie można wykluczyć, że specyficzny kąt padania światła wykorzystano już w szesnastowiecznym nagrobku, którego części zachowały się w kościele św. Idziego. Przyjmując jego rekonstrukcję zaproponowaną przez Katarzynę Sinko-Popielową, można przypuszczać, że światło padało wtedy na górną część nagrobka, w której znajdowała się figura świętego klęczącego przed Matką Boską ${ }^{47}$. Nie wiadomo, czy efekt ten wykorzystano również w kolejnym nagrobku, który mógł mieć formę edikuli ${ }^{48}$. Piskorski go wprawdzie nie widział w pierwotnym miejscu, ale pamięć o takim rozwiązaniu mogła przetrwać rozbiórkę, stając się dla niego jednym ze źródeł inspiracji.

Ułożone przez Piskorskiego koncepty aranżacji wnętrz kościelnych dostarczają wielu interesujących przykładów oryginalnego ukształtowania nastaw ołtarzowych, które można określić jako wybitne zarówno pod względem formalnym, jak i treściowym. Ich powiązanie $z$ konkretnymi datami za pomocą bezpośredniego wydobycia ukierunkowanym światłem słonecznym wydaje się najciekawszym ze stosowanych przez niego rozwiązań. Poza wspomnianym nagrobkiem św. Jacka, nie jest to, o ile wiadomo, znane z innych dzieł sztuki nowożytnej.

\footnotetext{
44 Na ustawienie figury na tle okna zwrócił uwagę Mariusz Karpowicz (KARPOWICZ 1994, s. 59).

45 Brzezina-Scheurer 2013, s. 676.

46 Taki efekt widoczny jest na obrazie Todora Baltazara Stachowicza, ukazującym wnętrze nawy

kościoła przed pożarem.

SINKO-POPIELOWA 1948, s. 83.

48 Jak zauważył Ryszard Mączyński, można przypuszczać, że nagrobek ten ukazano na rycinie Tobiasza Steckla we wspomnianej książce Frydrychowicza (MĄCZYŃSKI 2003, s. 504).
} 


\section{Bibliografia:}

\section{Źródła:}

- AKKK - Archiwum Klasztoru SS. Klarysek w Krakowie, B1, Inwentarz kościelnego skarbu, 1718.

- AUJ, Rkps 318 - Archiwum uniwersytetu Jagiellońskiego w Krakowie, Rkps 318, Rationes Preceptorum et Expensorum Pro Fabrica Ecclesiae S. Annae Crac[oviensis].

\section{Opracowania:}

- ACKERMANN 2007 - Felix Ackermann, Die Altäre des Gian Lorenzo Bernini. Das barocke Altarensemble im Spannungsfeld zwischen Tradition und Innovation, Petersberg 2007.

- BANIA 2007 - Zbigniew Bania, Od fundatora do wykonawcy. Twórcy architektury XVII-XVIII wieku w Polsce, [w:] Architekt - budowniczy - murator. Materialy z sesji naukowej Instytutu Sztuki PAN..., Warszawa 2007, s. 47-53.

- BARĄCZ 1888 - Sadok Barącz, Klasztór i kościót Dominikanów w Krakowie, Poznań 1888.

- BIAŁOSTOCKI 1962 - Jan Białostocki, Wstęp i Komentarze, [w:] Dwugłos o Berninim (Baldinucci i Chantelou), oprac. Jan Białostocki, Teksty źródłowe do dziejów i teorii sztuki, red. Juliusz Starzyński, t.11, s. IX-LV.

- BIERNACKA 1987 - Małgorzata Biernacka, Niepokalane Poczęcie, [w:] Maryja matka Chrystusa. Ikonografia nowożytnej sztuki kościelnej w Polsce, t. 1, red. Janusz Pasierb, Warszawa 1987, s. 27-92.

- BRZEZINA-SCHEURER 2013 - Katarzyna Brzezina-Scheurer, Z dziejów barokowego oltarza św. Jacka w kościele Dominikanów w Krakowie, [w:] Sztuka w kręgu krakowskich dominikanów, „Studia i źródła Dominikańskiego Instytutu Historycznego w Krakowie", red. Anna Markiewicz, Marcin Szyma, Marek Walczak, Kraków 2013, s. 669-682.

- BUCHOWSKI 1703 - Jan Buchowski, Gloria Domini super Templum [...] S. Annae [...], Cracoviae 1703.

- DEGREVE 2010 - Daniel P. DeGreve, Retro Tabulum. The Origins and Role of the Altarpiece in the Liturgy, „Sacred Architecture”, t. 17 (2010), s. 12-18.

- DI STEFANO 2007 - Elisabetta Di Stefano, Laltro sapere. Bello, Arte, Immagine in Leon Battista Alberti (="Aesthetica Preprint Supplementa" 4, IV 2000).

- DREŚCIK 1987 - Jan Dreścik, Kwiatki świętey pustynie B. Salomei Panny, na skale S. Maryey. Treści ideowe barokowej pustelni bł. Salomei w Grodzisku koło Skały, „Folia Historiae Artium”, nr 23, 1987, s. 37-81.

- DZIUBECKI 1987 - Tomasz Dziubecki, Dzieciństwo NMP, [w:] Maryja matka Chrystusa. Ikonografia nowożytnej sztuki kościelnej w Polsce, red. Janusz Pasierb, t. 1,Warszawa 1987, s. 94-118.

- FRYDRYCHOWICZ 1687 - Dominik Frydrychowicz, S. Hyacinthus Odrovasius Principalis Hierarchicus Universalis Regni Poloniae Patronus a Sede Apostolica Datus, ab Indigenatu Natus, ab Universis Polonis Rogatus, Cracoviae 1687.

- FÜRST 2002 - Ulrich Fürst, Die lebendige und sichtbare Histori. Programmatische Themen in der Sakralarchitektur des Barock, Regensburg 2002.

- HASKELL 1963 - Francis Haskell, Patrons and painters. A study in the Relations Between Italian Art and Society in the Age of the Baroque, London 1963.

- HOPKINS 2006 - Andrew Hopkins, Baldassare Longhena 1597-1682, Milano 2006.

- HUNDEMER 1997 - Markus Hundemer, Rhetorische Kunsttheorie und barocke Deckenmalerei. Zur Theorie der sinnlichen Erkenntnis im Barock, Regensburg 1997.

- KARPOWICZ 1994 - Mariusz Karpowicz, Baltazar Fontana, Warszawa 1994.

- KOWALSKI 2009 - Jacek Kowalski, Barok, [w:] Bogdan Hojdis, Jacek Kowalski, Katarzyna Meller, Literatura staropolska, Poznań 2009, s. 177-332.

- KUNKIEL 2007 - Robert Kunkiel, Zawód architekta w Polsce wieku XVI. Na marginesie przygotowywanego „Stownika architektów polskich $i$ w Polsce działających” [w:] Architekt - budowniczy - murator, red. Hanna Faryna-Paszkiewicz, Małgorzata Omilanowska, Jakub Sito, Warszawa 2007, s. 13-24. 
- KURZEJ 2008 - Michał Kurzej, Budowa i dekoracja kościoła św. Anny w świetle źródeł archiwalnych, [w:] Fides ars scientia. Prace z historii i historii sztuki poświęcone pamięci ks. Augustyna Mednisa, red. Andrzej Betlej, Józef Skrabski i in., Tarnów 2008, s. 271-301 (wznowienie [w:] Studia z dziejów kościoła św. Anny, red. Zdzisław Kliś, Tomasz Węcławowicz, Kraków 2009, s. 139-200 i wyd. II, Kraków 2011, s. 137-199).

- KURZEJ 2014 - Michał Kurzej, Ksiądz Sebastian Piskorski a sztuka i historia, [w:] Sztuka po Trydencie, „Studia de arte moderna”, t. 1, red. Kazimierz Kuczman, Andrzej Witko, Kraków 2014, s. 415-428.

- KURZEJ 2015 - Michał Kurzej, Świątynia Mądrości. Program treściowy wystroju kościoła św. Anny w Krakowie, „Folia Historiae Artium”, t. 13 (2015), s. 119-152.

- KURZEJ 2016a - Michał Kurzej, Aranżacja prezbiterium kościoła Klarysek w Starym Sączu, „Modus”, t. 16, (2016), s. 15-25.

- KURZEJ 2016b - Michał Kurzej, The iconographic programme of the Poor Clares' church in Cracow, „Folia Historica Cracoviensia", t. 22 (2016), s. 189-210.

- MAHON 1947 - Denis Mahon, Studies in Seicento art and theory, London 1947.

- MAŃKOWSKI 1946 - Tadeusz Mańkowski, Fabrica ecclesiae, Warszawa 1946 (Prace z historii sztuki 5).

- MATTEINI 2013 - Federica Matteini, Orsini Fulvio [w:] Dizionario Biografico degli Italiani, 79, 2013, www. treccani.it/enciclopedia/fulvio-orsini_\%28Dizionario_Biografico\%29/.

- MAŚLIŃSKA-NOWAKOWA 1966 - Zofia Maślińska-Nowakowa, Rola tekstu literackiego $w$ kształtowaniu dekoracji barokowego wnętrza kościoła św. Anny w Krakowie, 1966, praca doktorska pod kierunkiem prof. Adama Bochnaka w Archiwum Uniwersytetu Jagiellońskiego.

- MĄCZYŃSKI 2003 - Ryszard Mączyński, Nowożytne konfesje polskie. Artystyczne formy gloryfikacji grobów świętych i błogosławionych $w$ dawnej Rzeczypospolitej, Toruń 2003.

- MĄCZYŃSKI 2014 - Ryszard Mączyński, Mączyński, Grób świętego ozdobić godnie. Artystyczne dylematy twórców nowożytnych konfesji, [w:] Sztuka po Trydencie, „Studia de arte moderna”, t. 1, red. Kazimierz Kuczman, Andrzej Witko, Kraków 2014, s. 55-67.

- MĄCZYŃSKI 2015 - Ryszard Mączyński, „Koncept nowy” jako wyznacznik wartości artystycznej druków propagujących kult świętych, [w:] Staropolska literatura dewocyjna. Gatunki, tematy, funkcje, red. Iwona M. Dacka-Górzyńska, Joanna Partyka, Warszawa 2015, s. 213-224.

- MORANDOTTI 2000 - Alessandro Morandotti, Paolo Pagani e i Pagani di Castello Valsolda, Lugano 2000.

- PISKORSKI 1691 - Sebastian Piskorski, Flores Vitae B. Salomeae virginis, pincipis Poloniae, reginae Haliciae, Ordinis S. Clarae primae in Polonia fundatricis, iconibus, hierogliphicis, lemmatis, epigrammatibus explicatius vernantes, Cracoviae 1691.

- RECHOWICZ - Marian Rechowicz, Św. Jan Kanty i Benedykt Hesse w świetle krakowskiej kompilacji teologicznej z XV w. Studia nad komentarzem do św. Mateusza, Lublin 1958.

- SIEJKOWSKI 1743 - Michał Siejkowski, Świątnica Pańska to jest Kościół Boga w Trójcy SS. jedynego z klasztorem WW. OO. Dominikanów w Krakowie..., Kraków 1743.

- SINKO-POPIELOWA 1948 - Katarzyna Sinko-Popielowa, Zaginiony nagrobek św. Jacka w Krakowie, „Prace Komisji Historii Sztuki", t. 9 (1948), s. 66-87.

- TOESCA, ZAPPERI 1960 - Ilaria Toesca, Robereto Zapperi, Agucchi, Giovanni Battista [w:] Dizionario Biografico degli Italiani, t. 1 (1960), http://www.treccani.it/enciclopedia/giovanni-battista-agucchi_\%28Dizionario_Biografico\%29/

- WARDZYŃSKI 201 - Michał Wardzyński, Marmur i alabaster w rzeźbie i małej architekturze Rzeczypospolitej. Studium historyczno-materiałoznawcze przemian tradycji artystycznych od XVI do poczatku XVIII wieku, Warszawa 2015.

- ZAGÓROWSKI 1959 - Olgierd Zagórowski, Rzeźbiarz Antoni Fraczkiewicz, „Biuletyn Historii Sztuki” t. 21 (1959), nr 1, s. 120-121.

- ZAPLETALOVÁ 2005 - Jana Zapletalová, Mezi Boloňou a Krakovem. Život a dílo italského malî́re Innocenza Montiho (1653-1710), „Umění”, t. 53 (2005), s. 335-346.

- ZAPLETALOVÁ 2007 - Jana Zapletalová, Působení Innocenza Montiho v Krakově, [w:] Barok i barokizacja. Materiały sesji Oddziału Krakowskiego Stowarzyszenia Historyków Sztuki, Kraków 3-4 XII 2004, red. K. Brzezina, J. Wolańska, Kraków 2007 (=Ars Vetus et Nova, red. W. Bałus, 28), s. 205-214.

- ZOVATTO 1970 - Paolo Lino Zovatto, La basilica di santa Giustina. Arte e storia, Pavia 1970. 


\section{The Altar as a Window and a Mirror in the concepts by Rev. Prof. Sebastian Piskorski}

$\mathrm{T}$ he metaphor of the altar as a window and a mirror is particularly suitable for a series of reredoses designed by Rev. Prof. Sebastian Piskorski, a professor of law at the JagiellonianUniversity, and a popular poet and preacher, who became a central figure of the artistic life, participating as a conceptor and administrator in the process of creating the most interesting complex works of holy art. And the reredoses of these works play a crucial role there, since they become a key which enables us to read the iconographic programme. Besides its common decorative function of the presentation of a supernatural reality, they also work as a mirror. At certain times, they take the sunlight that generates a short-lived effect within the reredos, opening a new meaningful layer for the audience. The very first work by Piskorski is the pilgrimaging establishment in Grodzisknear Skała, conducted between 1677 and 1691. It commemorates Blessed Salomea, who is said to have lived and eventually died there on 17 November 1268. Its chapel was designed in such a manner that,on that day,sunshine flooded her altar. In 1692,Piskorski was offered an opportunity to applysignificantly more magnificent artistic solutions, when the university charged him with the task of managing the construction works of the new collegiate of St. Anne. Presumably, he participated in a debate on the location and the design of the church in order to influence the positioning and arrangement of its main reredoses. Due to their specific deployment, sunlight could be used to connect the altars in the presbytery and both wings of the transept with the stages of the sun year. A significant element of the interior is the altar with relics of the university's patron saint-Saint John Cantius. The key to comprehending its form is the cult which was built up around him, propagated by the legend according to which he obtained a supernatural illumination from Jesus Christ himself. In the mausole- 
um, this illumination was depicted by the Lamb and a putto with the following inscription: 'Et lucernaeiusest', which points to the relics carried by personifications of the four faculties. The pillars that surround the grave are references to the white-stone supports, which - as tradition has it - originate from Salomon's Holy Temple. On the supports, there stand the statues of Cantius' blessed namesakes, who - just like him - were preachers and theologists. One of them, John the Baptist, points to the Lamb's image, which, at the same time, is his attribute, reminding the onlookers that Cantiusbore his first name to honour him and was born on his feast day, which falls on the summer solstice. In the afternoon around that date, sunlight floods this composition, highlighting its meaning and indicating that Providence destined Cantiusfor sanctity. The light is reflected off the statue of the Lamb and its aureole, like in a mirror, and then it floods onto the worshippers who are kneeling in front of the altar.This can be interpreted as the act of transferring the illumination once granted to the saint himself. The design of two out of the three most important altars within the collegiate also involves the sunlight-reflecting effect. Opposite Cantius' grave, there is a relief portraying the triumph of the Cross, adored by Saint John the Evangelist and the Mother of God who is supporting the dead body of Christ. In the mornings on the days around the equinox, sunlight floods this part of the composition, commemorating the date of Jesus's death. The painting in the high altar is illuminated at the turn of December and January, when - in the evenings - aray of sunlight creates a natural aureole above the heads of the depicted figures. The most important of these is the Baby Jesus, whose birth was commonly associated with the winter solstice and the eve of this celebration is also the anniversary of Cantius' death. The use of natural lighting within the interior of the church is associated with the works by Bernini, who introduced the light into the composition from a hidden source, i.e. in a fashion which,to a great extent,was independent of the season or the time of day. Piskorski, on the other hand, used direct sunlight, which, just like a spotlight, picks out a specific element of the interior for a short period of time, from several to a dozen or so days in the year. 